\title{
Orthopaedic Education in Indonesia
}

\author{
M. Ahmad Djojosugito *
}

\begin{abstract}
Abstrak
Pendidikan dokter spesialis bedah ortopedi yang formal dan terstruktur, yang dimulai tahun 1968 di Fakultas Kedokteran Universitas Indonesia, merupakan upaya bersama antara pemerintah (Departemen Pendidikan dan Kebudayaan) sebagai pemilik otoritas birokrasi dengan organisasi profesi (Perkumpulan Dokter Spesialis Bedah Ortopedi Indonesia) sebagai pemilik otoritas profesional. Kurikulum disusun oleh perhimpunan profesi dan ditetapkan dengan surat keputusan pemerintah (Depdikbud), akreditasi dan sertifikasi ditetapkan bersama. Fakultas kedokteran bersama rumah sakit pendidikan bertindak sebagai pelaksana kebijakan pendidikan yang ditetapkan bersama antara pemerintah dan perhimpunan profesi. Peran dari spesialis bedah orthopaedi dari Australia, Canada, Amerika Serikat dan Singapore, yang dikoordinasi oleh Care Medico Orthopaedic Overseas pada awal dimulainya pendidikan, adalah sebagai inisiator, inovator dan pengembang program pendidikan. Saat ini penguji luar dari Australia dan negara Asean, berperan sebagai penjaga mutu lulusan. Sebagai kesimpulan dapat diutarakan bahwa kerjasama sinergis antara pemerintah dan organisasi profesi merupakan cara terbaik untuk menghasilkan dokter spesialis bedah ortopedi yang bermutu, serta sesuai dengan kebutuhan masyarakat dan selaras dengan kemampuan anggaran pemerintah.
\end{abstract}

\begin{abstract}
Formal and structured orthopaedic education in Indonesia, which was started in 1968 at the Faculty of Medicine, University of Indonesia, had been a joint effort and synergy between the government (Ministry of Education) as the bureaucratic authority and the professional organization (Indonesian Orthopaedic Association) as the professional authority. The curriculum is set up by the Orthopaedic Association and approved by the government, credentialing (accreditation and certification) was done jointly by the government and the professional organization. The Faculty of Medicine of the universities, in cooperation with the teaching hospitals, serve as the implementor of the joint policies of both authorities. The role of the Australian, Canadian, American and Singaporean orthopaedic surgeons at the beginning of the education program, which were coordinated by Care Medico Orthopaedic Overseas was, as the initiator, inovator and the enhancer of the education program. At present the external examiner from Australia and Asean countries, act as the quality enhancer and quality benchmarker of the graduates. In conclusion, this kind of synergy is considered as the best method in graduating the good quality orthopaedic surgeons, yet in conformance with the need of the people and with the capability of the government budget.
\end{abstract}

Keywords : Professional authority, Bureaucratic authority, Synergy, Curriculum, Credentialing, Certification and accreditation

\section{HISTORICAL BACKGROUND}

Medical education in Indonesia started in 1851 by the Dutch colonialist, to provide cheap indigenous public health worker, which was named "Javanese Doctor", whose responsibility was mainly environmental hygiene and vector/rodent control. Around 1910 the Dutch started the structured medical education, which was hospital based, using the Dutch military hospital.

\footnotetext{
* Orthopaedic Division Department of Surgery,

Faculty of Medicine, University of Indonesia / Dr. Cipto

Mangunkusumo Hospital, Jakarta, Indonesia.
}

In 1919 the Central Government Hospital was founded in Jakarta and was used as teaching hospital (After the Indonesian independence, this hospital was later named after one of the Indonesian national hero : "Doctor Cipto Mangunkusumo National Referral Hospital"). The teaching method was mainly traditional apprenticeship training.

After the independence in 1945 the Dutch system was continued. In 1950, the University of Indonesia was founded, and the Faculty of Medicine was the continuation of the Colonial School of Medicine. The apprenticeship method was dominant, with slow or few output.

By 1955 the guided structured medical education was introduced and was developed by the assistance of the 
University of California, which produce more output. However, for postgraduate specialty training, the apprenticeship training was still maintained. Certification was given by the professor of each specialty. No accreditation to the hospital which was used as the teaching hospital for specialty training.

Between 1960 and 1970, the professional organization started to accredit the hospital which was used for specialty training. The accreditation team of the professional organization consists of all professors of the medical specialties of all universities in Indonesia. However the certification was still given by the professor of each specialty and approved or witnessed by the Dean of Medical School.

Between 1978 and 1980 the Government (The Ministry of Education) took over all kinds of educational responsibility, including postgraduate medical specialty training. Due to this policy, the certification was then given by the Rector (President) of the University after approving the report of the training program from the Dean, and the Dean received the report from the Training Program Coordinator who approved the report of each Specialty Training Program Director.

This paper is a report on how this system and procedures works in Orthopaedic Training Program in Indonesia.

\section{ORTHOPAEDIC TRAINING PROGRAM IN INDONESIA}

Since 1955 some general surgeon were sent abroad for training in orthopaedic surgery, and when they came back, they had to share their skill and knowledge to the residents in general surgery, using apprenticeship method but there was no formal orthopaedic training program.

In 1968, Care Medico Orthopaedic Training Program in Jakarta, which was run by the Care Medico Orthopaedic Overseas, was started. The teacher for this program mainly came from Canada, Australia and United States, and they came for one month to teach orthopaedic knowledge and skill, using Indonesian patients with Indonesian hospital setting. Examination was done by the program with examiner from abroad. Up to 1975 has graduated 12 orthopaedic surgeons, and since then the program was continued by the University of Indonesia in Jakarta. However to maintain the quality of the graduates, the program always invite external examiner, mainly from Australia and Singapore, for the final examination.
In 1978 the government took the responsibility of all kinds of education, include postgraduate for medical discipline, started with 14 postgraduate programs. At the 4th National Congress of the Indonesian Orthopaedic Association 1981, the Minister of Education and Culture through the Director General of Higher Education and CHS decided that the postgraduate program of orthopaedic surgery should be started and the candidate is not necessary to be a qualified general surgeon as before but those medical doctor who has finished the national service as doctor in the health centers (Puskesmas). Two medical faculties, University Indonesia in Jakarta and University Airlangga in Surabaya were appointed to run the postgraduate program started in 1982 following the catalog of training program 1981.

At present there are three center of orthopaedic training / education program in Indonesia namely University of Indonesia, Jakarta, University of Airlangga, Surabaya and University of Padjadjaran, Bandung. Each training program is managed by the Education Program Director (in Indonesia : Ketua Program Studi / KPS) with the assitance of the Secretary of the Program (in Indonesia: Sekretaris Program Studi/SPS), and both are appointed by the Rector / President of the University and are chosen among the candidates proposed by the Dean of Medical Faculty, who received the names of the candidates from the head of the Department of Orthopaedic Surgery.

Concerning policy decision in orthopaedic education, in every Congress of the Indonesian Orthopaedic Association (which is held every three years), the Congress appoints five members of the Board of Orthopaedic Surgery, a Board which formulates the policies on Orthopaedic Education, evaluates / monitor the implementation of the policies, and which also audits ethical conduct of the surgeons. From the government site, the Consortium of Health Science (CHS) of the Ministry of Education appoints three members of Board of Study (BOS) / Orthopaedic, whose names are proposed by the Indonesian Orthopaedic Association. The names proposed by the association are usually also faculty member of a government university. This Board of Study / Orthopaedics plays role as a liaison between government (Ministry of Education / CHS and Ministry of Health) with the professional organization (Indonesian Orthopaedic Association).

The office bearer of the Indonesian Orthopaedic Association, after discussing with the members of Indonesian Board of Orthopaedic Surgery, the members 
of Board of Study / Orthopaedic and with the Program Director of the three Universities, appoints the Chairman, secretary and members of Committee on Examination and Qualification, a Committee which implement the policies of the Board of Orthopaedic Surgery concerning the Education and which hold the National Board Examination. The Committee appoints the examiner for every examination, including external examiner who are from Singapore and Australia regularly, and sometime from USA, France, Japan and Malaysia. The internal examiner comes from the three Universities (the Program Director and the Secretary), the Indonesian Board of Orthopaedic Surgery, the member of Board of Study / Orthopaedics.

\section{RECRUITMENT AND SELECTION}

Recruitment and selection is done by Program Director of each university. The candidate has to apply to the Ministry of Health, who identify whether the candidate has fulfilled the compulsory service as Medical Doctor (usually in a remote area of Indonesia). The candidate who has fulfilled the compulsory service is then sent to the Consortium of Health Science, who will register the application and send the application to University concerned, to be conveyed to the Program Director.

The selection which is done by the Program Director, is written and oral selection. The admission to the program is based on a certain criteria which identify his or her intelligence and creativity, clinical skill, enthusiastic commitment to Orthopaedics, integrity in practicing medicine, compassionate, as well as his or her maturity, leadership and good health.

The names of the accepted candidate are sent to the Consortium of Health Science through the University and the Consortium send the names to the Ministry of Health, which then announce the acceptance to each candidate.

\section{CURRICULUM}

The objectives of the curriculum is to graduate a comprehensively clinically competent orthopaedic surgeon, who is committed to quality patient care, who has a sound knowledge of orthopaedics and has appropriate operative skill.

The structure of the curriculum consists of two parts, basic surgery (including basic orthopaedics) which lasts for two years and advance orthopaedic surgery which lasts for 2.5 years. Basic surgery is held in the
Department of Surgery and the examination of this part is a National Board Examination which held by the Indonesian College of Surgeons. The second part is held in the Department / Section of Orthopaedic Surgery of the three universities and the examination of this part consists of two examination, first the examination by the Department of each University and secondly the National Board Examination, which is held by the Committee for Examination and Qualification of the Indonesian Orthopaedic Association.

The contents of the curriculum ; the first part contains general digestive surgery (adult and child), general traumatology, general surgical infection, general oncology, basic orthopaedic surgery, basic plastic surgery and neurosurgery. The second part contains orthopaedic adult trauma and reconstructive surgery (advance), pediatric orthopaedic, orthopaedic oncology, hand surgery, spine surgery and orthopaedic rehabilitation.

Evaluation of the resident / trainee is in relation with his or her knowledge, skill and attitude. The knowledge is monitored by regular test and examination part by part ; while the skill is monitored using work book, and the attitude is monitored by the seniors and the peers. All feedback is reviewed and concluded by regular staff meeting.

\section{CREDENTIALING}

Credentialing consists of two part, firstly the accreditation of the program and secondly certification of individual resident / trainee. The accreditation is to evaluate the compliance of the program in a specified university with the standard published. The certification is to evaluate whether the accredited program results in a graduate who possess the knowledge, skill and attitude, necessary to meet the established educational standard.

\section{ACCREDITATION}

The accreditation standard and educational standard were developed jointly by the Consortium of Health Science and the Indonesian Orthopaedic Association, through several meetings and discussions, and decided and published by the Ministry of Education.

The accreditation standard contains the requirement of the teaching staff (the number, the experience, the previous performance in education and research, the credibility and integrity), the requirement of the affiliated hospital with its department of orthopaedic 
surgery (the number and utilization of orthopaedic beds, the spectrum of cases and operations, the scientific and research as well as ethical atmosphere), the requirement of the educational hardware and software (library, lecture / discussion room, teaching method), the requirement of the support system for orthopaedic service, teaching and research (other clinical and non clinical department of the hospital / faculty of medicine especially laboratory, radiology, operating theater and rehabilitation department).

The candidate to be accredited (namely the department of orthopaedic surgery of a certain university) has to apply to the Consortium of Health Science through the Dean and the Rector of the University, enclosing the required paper namely the statement from the "academic society" in the teaching hospital / university, that the society needs the establishment of orthopaedic training in the university / teaching hospital, the statement of the need of establishing orthopaedic training program in that teaching hospital / university from the Indonesian Orthopaedic Association, the statement from the older accredited Department of Orthopaedic Surgery which previously assists the candidate to establish training program, that the candidate is ready to run a program by itself. Beside that the required paper mentioning the data and information which showed that the candidate has met the established standard for accreditation is also enclosed. After making several visitation and correction by CHS, which resulted in the approval by the CHS, this result is then reported to the annual regular plenary meeting of the CHS with all the deans of faculty of medicine of all government universities. The last approval from this forum is then formalized by a letter of decision by the Minister of Education, mentioning the candidate as an accredited institution for orthopaedic training program.

The accreditation status as well as the accreditation standard and the educational standard are regularly re-evaluated by the government (Board of Study Orthopaedics / CHS / Ministry of Education) jointly with the professional organization (the Indonesian Orthopaedic Association through the Indonesian Board of Orthopaedic Surgery and the Committee on Examination and Qualification).

\section{CERTIFICATION}

The educational standard contains the requirement of the level of knowledge and skill which has to be met by the resident / trainee, and of the attitude needed by the resident to be enthusiastic, compassionate, credible and having integrity. It also contains the performance measurement of the knowledge and skill of the resident.

Certification is given after two step of examination, the examination held by the department of orthopaedic surgery of each university and the National Board Examination held by the Comittee on Examination and Qualification of the Indonesian Orthopaedic Association. After passing these examination, a candidate is awarded a certificate of accomplishment from the Rector of the University concerned, after the Rector received the report of the accomplishment from Program Director.

\section{DISCUSSION}

Since 1955, when the graduate medical education was stuctured in a "guided structured education", the postgraduate medical education for specialty in medicine and surgery was still using traditional apprenticeship training method. This was done in order to maintain the quality of the specialist. Credentialing was done by the "guru" who is usually the professor of the specialty concerned.

By 1978 when the goverment took the responsibility of all kind of education in the country, the specialty training was structured by joint effort of the government and professional organizations. From that time on the credentialing was done by the government in cooperation with professional organization (through "CHS" and "BOS").

Actually in both method, the center of the training is still in the professor (the "guru"). The difference is that in the old method, the speed of the training as well as the number of the graduate, can not be monitored and controlled by the government ; while in the new method the speed and the number of graduate can be planned together jointly between government and professional organization, without jeopardizing the quality of the graduate. This is good and needed by the population, especially in Indonesia with 200 million of population with only 150 orthopaedic surgeons. In this method we can see a synergy between government as the owner of administrative power, with the professional as the owner of professional power as well as "marketing" power. I stated "marketing" here because we realized that with whatever reason, health care has two aspect, one aspect as social responsibility of the professionals and another aspect as "commodity" in health "industry". This two aspect is something like the two side of one coin, the "coin" of health care. 
The balance between these two power is good for the people. In country where the professional organization is too strong, the market law together with "the law of medical money", will cause the cost of health care increased higher with the inflation rate of money ; while in country where the government is very strong, there is no competition among the professionals and the motivation of the professional to serve a better service so that better education is also not needed. Both condition is not good for the population.

Concerning the standard, even the government and the professional organization do their best to benchmark the quality of the training to the established western standard, the problem of funding is the cause why those work can not optimally accomplished. The other problems which are still on the way of our development, which need more prioritization, make us has to work much more harder.

\section{CONCLUSSION}

The education of orthopaedic surgeons in Indonesia is a joint effort between government and professional organization. This partnership and synergy is currently the best method in providing a good quality orthopaedic surgeon to serve the population, which is in conformance with the need of the people and with the ability of the government to provide the fund for development.

\section{REFERENCES}

1. Allen WC. The relationship between residency programs and fellowships in the educational setting, Clin Orth Rel Res 1990; $257: 57-60$.

2. Beetham R. Experience as chairman of the Orthopaedic Training Programme in Indonesia. In: Pillay VK, Chacha PB. Proceedings of the second International Symposium on Orthopaedic Training in Developing Countries, Singapore 1975; 74-5.

3. Burton RI. Credentialing for International Fellowship, Clin Orth Rel Res 1990; 257:61-3.

4. Hilmy CR, Reksoprodjo S. Period of Transition in the Orthopaedic Training Programme in Indonesia. In Pillay VK, Chacha PB. Proceedings of the second International Symposium on Orthopaedic Training in Developing Countries, Singapore 1975; 70-3.

5. Ron C et al. Characteristics of Successful and Unsuccessful Applicants to Orthopaedic Residency Training Programs, Clin Orth Rel Res, 1989; 241:257-64.
6. Clunie GJA. Surgical Training links between the United Kingdom and Australasia, Editorial Comment, Aust NZJ Surg 1993; 63:85-86.

7. Djamaloeddin. Orthopaedic Training in Indonesia. In: Pillay VK, Chacha PB. Proceedings of the second International Symposium on Orthopaedic Training in Developing Countries, Singapore 1975; 120-23.

8. Ebert PA. Method for Evaluation of Medical Care other than Credentialing, Cost, Experience and Results, Clin Orth Rel Res 1990; 257:64-6.

9. Hilmy CR, Djojosugito MA. The Orthopaedic Surgeon in Indonesia : the need, their training and their role in our society, Proceedings of the first Congress of the Indonesian Orthopaedic Association, Jakarta, 1974.

10. The Indonesian Orthopaedic Association. Curriculum for the Orthopaedic Training Program, J Indon Orth Ass 1975; 1:72-89.

11. Lange V. The Australian Orthopaedic Volunteer Nursing Program, In: Pillay VK, Chacha PB. Proceedings of the second International Symposium on Orthopaedic Training in Developing Countries, Singapore, 1975; 150-1.

12. Leung PC. Educational Objectives in Orthopaedic Training, paper presented at the Discussion on Accreditation and Surgical Training, Asia Pacific, RACS Annual Meeting, Canberra, 1992 (unpublished).

13. Maloney JV. Education in Thoracic Surgery : Personal and Societal Influences, Ann Thorac Surg 1993; 55:1337-9.

14. Reksoprodjo S, Hilmy CR. The Value of In-country Training as opposed to going to Overseas Centres. In: Pillay VK, Chacha PB. Proceedings of the second International Symposium on Orthopaedic Training in Developing Countries, Singapore, 1975; 68-9.

15. Reksoprodjo S. Organization and Financing of the Indonesian Orthopaedic Training Programme. In: Pillay VK, Chacha PB. Proceedings of the second International Symposium on Orthopaedic Training in Developing Countries, Singapore, 1975; 135.

16. Sheldon GF. Recruitment and Selection of the "Best and Brightest", Ann Thorac Surg 1993; 55:1340-4.

17. Sjamsuhidajat R. Responsibility of established Colleges to the Developing World : the Case of Indonesia, paper presented at the RACS Annual Scientific Congress, Adelaide, 1993 (unpublished)

18. Sukarna IP, Roeshadi D. One Country Report - Indonesia, The Progress of Orthopaedics in Surabaya. In: Pillay VK, Chacha PB. Proceedings of the second International Symposium on Orthopaedic Training in Developing Countries, Singapore, $1975 ;$ 92-3.

19. Urbaniak JR. Certificates of Added Qualifications in Orthopaedic Surgery, Clin Orth Rel Res 1990; 257:52-6.

20. Wilson FC. The Credentialing of Orthopaedic Fellowship, Editorial, J Bone Joint Surg 1988; 70A:799-801.

21. Wilson FC. The Accreditation of Graduate Educational Programs in Orthopaedic Surgery, Clin Orth Rel Res 1990; 257:18-21.

22. Wilson FC. Credentialing in Medicine, Ann Thorac Surg $1993 ; 55: 1345-8$. 